\title{
Previous Witness testimony as immediate or URGENT ACTION AND ITS ADMISSIBILITY IN COURT
}

\author{
Veronika Pochylá
}

\section{Faculty of Law, Palacký University Olomouc, Czech Republic email: veronika.pochyla@upol.cz}

POCHYLÁ, Veronika. Previous witness testimony as immediate or urgent action and its admissibility in court. International and Comparative Law Review, 2015, vol. 15, no. 2, pp. 145-159. DOI: 10.1515/iclr-2016-0041.

\begin{abstract}
The paper deals with the admissibility of witness testimony in the preliminary proceeding which could be read in court without right of the defence to hear or examine such a witness. This question is particularly interesting with regard to preserving the adversarial principle which is important for an objective assessment of the facts. The focus will be to answer the question of whether so obtained and executed evidence may stand as the main evidence of guilt especially with regard to Article 6,par. 1 and 3 (d) ECHR (right to obtain attendance and examination of witnesses). The arguments in this paper will be submitted supported by the case law of the Constitutional Court of the Czech Republic and the ECtHR. Contribution will also deal with British law and the applicability of the so-called Hearsay rule and the exceptions to this rule which can be applied in criminal proceedings.
\end{abstract}

Keywords: Adversarial principle; contradictory; fair trial; testimony; witness; urgent or unrepeatable act; admissibility of evidence; read testimony; absent witness; Hearsay rule.

\section{Introduction}

According to current Czech legislation, if there is a presumption (because of the lack of facts identified by the police authority) that a crime was committed and that it was committed by a suspect, are bodies of the criminal proceedings obliged to prosecute it under $\$ 160$ par. 1 Criminal Procedure Code. However there may be situations where, for some reasons, a person suspected of committing a crime cannot be served with the indictment and therefore prosecuted, but it is still necessary to carry out some of the evidence, because they could be destroyed or lost, and therefore they would not be presented before the court, or because this evidence couldn't be repeated at hearing. These urgent or unrepeat-

1 Článek vznikl za finanční podpory projektu IGA_PF_2015_012 - Postup před zahájením trestního stíhání: efektivita a ústavněprávní konformita.

2 Mgr. Veronika Pochylá, Palacký University Olomouc, Faculty of Law, Czech Republic; email: veronika.pochyla@upol.cz 
able acts and in particular the applicability of the protocol of their implementation are set forth in $\$ 160$ par. 4 of the Criminal Procedure Code. ${ }^{3}$

If the proof was obtained in a lawful manner, there will be a protocol of such a pursuance and this can be read in a court. ${ }^{4}$ But just reading the protocol on the implementation of an urgent or unrepeatable act may make a defendant feel as an interference with his protected rights or interests, because it may seem that such a process interferes with his right to a fair trial, with his rights to defined oneself, and that such a procedure leads to restriction of the adversarial principle and principle of direct proceeding, as one of the fundamental principles of criminal procedure and, by extension, the attributes of a democratic rule of law. ${ }^{5}$

Some of the urgent or unrepeatable acts are directly enumerated by the Criminal Procedure Code in the ninth head the second par. (Procedure prior to the commencement of prosecution). Out of those that are expressly provided by the Criminal Procedure Code, the following text will address the examination of a witness by $\$ 158$ a of the Criminal Procedure Code, regulation of its course, the applicability of the Protocol on such questioning, and especially constitutional conformity of such evidence as main evidence, incriminating and convicting.

\section{The Czech legislation}

\subsection{Examination of witnesses as urgent or unrepeatable act}

According to $₫ 158$ a of the Criminal Procedure Code, it is necessary for the identification of the offender to carry out urgent or unrepeatable act consisting e.g. questioning of a witness, if within the verification of certain facts suggest that a crime was committed. Such a questioning must be conducted solely on Order of the public prosecutor and in front of a judge. The presence of a prosecutor, who ordered the urgent or unrepeatable measure, however, is not required by law. ${ }^{6}$

As also in the past the Constitutional Court on several occasions stated, the body that performs urgent or unrepeatable measure is obliged to thoroughly examine the conditions and facts, upon which is the act constituted as urgent or unrepeatable and explain its conclusion. ${ }^{7}$ Otherwise, if it would not be if substantiated in reviewable way, why the performance of an act (examination of

3 Code No. 141/1961, Criminal Procedure Code.

$4 \$ 211$, par. 2, point b) of the Criminal Procedure Code.

5 ÚS vol. 62, No. 129 Collection of the Judgements and Decisions. In JELÍNEK, Jiří. Trestní zákoník a trestní rád s poznámkami a judikaturou. 5. vydání. Praha: Leges, 2014, s. 916.

6 But he usually participates in such acts.

7 FRYŠTÁK, Marek. Zahájení přípravného řízení provedením neodkladných a neopakovatelných úkonů. Trestněprávní revue, 2013, No. 5, p. 109. 
witnesses) could not have been postponed to a later stage of the criminal proceedings, such a procedure would be found unconstitutional. ${ }^{8}$

This action takes place in the pre- prosecution stage of criminal proceedings when even accused cannot be on his own (or through his attorney) present at such an act, or to ask a witness further questions ${ }^{9}$, therefore, to exercise their right to defence, arising from Art. 38 par. 2 of the Charter of Fundamental Rights and Freedoms (CRF) and Art. 6, par. 3, point. d) of the European Convention on Human Rights (ECHR). To guarantee the legality of this phase, the law requires that such action must be conducted in the presence of judge, only then could be the report on the interrogation of a witness later used as evidence in court. It could be noted that the Criminal Procedure Code does not require that the judge who present at the questioning of a witness in accordance with $\$ 160$ par 4 of the Criminal Procedure, to be, excluded from further stages of the case, respectively from performing acts of criminal proceedings. In my opinion, the presence of the judge at the questioning of a witness in pre-trial process as urgent or unrepeatable act is comparable to his procedural status as an authority that ordered the searched of house in pre-trial process, decided on detention or handed out an arrest warrant.

These above enumerated facts constitute a prerequisite for exclusion of the judge from further proceedings ex lege. ${ }^{10}$ However, if the purpose of the exclusion of the judges from other acts carried out in criminal proceedings should be securing the confidence of the parties and the public in the impartiality of the process of bodies involved in criminal proceedings, all the more should the list include the exclusion of the judge in the case of their pre-trial participation in the questioning of a witness ${ }^{11}$ conducted as urgent or unrepeatable act in accordance with $₫ 158$ a of the Criminal Procedure Code. Current legislation does allow that the judge could be disqualified from deciding the case, if there are doubts about his partiality toward the merits of the present case, toward the parties involved in the case (directly affected) ${ }^{12}$, however, the subjective feeling of the judges about the condition for his or her exclusion is not in accordance with the case law decisive whether assessing the question of ability to carry out acts of criminal proceedings impartially. ${ }^{13}$ Incorporating the fact that the judge took part in the interrogation of a witness or recognition under $\$ 158 \mathrm{a}$ of the Criminal Procedure Code to the grounds for exclusion in $\$ 30$ par. 2 and 3 of the Criminal Code, should, in my opinion, prevent speculation and consideration of possible influence of judges by the result of such pre-trial actions and would

8 cf. finding of the Constitutional Court from the date 25. 8. 2008, sp. zn. IV. US 1780/07, published in the Collection of Judgments and Decisions N 147/50 Sb.

9 ŠÁMAL, Pavel a kol. Trestní ŕád. Komentár. 7, vydání. Praha: C. H. Beck, 2013, p. 1224.

$10 § 30$ par. 2, 3 of the Criminal Procedure Code.

11 or recognition in

$12 \$ 30$ par. 1 of the Criminal Procedure Code

13 Compare with PR 8/1997, p. 436. 
facilitate the process of exclusion of the judge judges from further stages of the criminal proceedings.

Unrepeatable act will mostly be the interrogation of the underage witness - a person under fifteen years of age, person who has been injured on his health by the crime, who lost his or her property or that, at whose expense the offender has unjustly enriched, if it is a person who's life is in danger, either because of very old age, or health condition, a person who is going abroad for a long period of time or a person who is a foreign national (or person without Czech citizenship and permanent residence permits in the Czech Republic). The order is issued by the prosecutor supervising the lawfulness of pre-trial proceedings in a particular case to the judge hearing the applications in area in which the state prosecutor, who issued the order, conducts his activities. ${ }^{14}$ The Criminal Procedure Code does not require certain form for a proposal so it can be inferred that such a proposal may be submitted not only in writing but also verbally, by phone or fax. In the latter cases it is necessary to make a note of this informal proposal in the report on the implementation of such an urgent or unrepeatable act. Judge hearing the application is also not entitled ${ }^{15}$ to review the nature of such testimony as an urgent or unrepeatable act and his authorization does not need to contain justification on what facts he came to the conclusion that the testimony must be performed before initiating the prosecution.

Interrogation is usually done by police and prosecutor at whose order the act takes place. Judge guarantees (by his or her presence) the rule of law, in the course of questioning intervenes only when necessary, in no case assumes the role of the police authority or prosecutor. His role is to impartially oversee the process of questioning from the point of view of legality, not the conduct evidence to the benefit or detriment of a person suspected of committing a crime. M. Fryšták wonders if in this stage the present judge should not already have a right to examine the order of the public prosecutor on the grounds that it might circumvent the law. ${ }^{16}$ I fully agree with this proposal, because at a later stage (in court), the court will have to deal with the conditions under which the interrogation was conducted, if they really and materially constituted urgent or unrepeatable act.

Another proposed right for a judge according again to M. Fryšták could be strengthening of the position of the judge in terms of intervention in the performed act from the material standpoint, including the right to question the witness. ${ }^{17}$ With this proposal I however could not agree. The judge has to provide

$14 \$ 26$ par. 2 of the Criminal Procedure Code

15 In contrast to e.g. The authorization to carry out a house search or search of other premises before the criminal prosecution as urgent or unrepeatable act.

16 FRYŠTÁK, Marek. Zahájení prrípravného řízení provedením neodkladných a neopakovatelných úkonů. Trestněprávní revue, 2013, No. 5, p. 113.

17 Ibidem. 
objective and impartial assurance of legality, his role is not to replace one of the parties, specifically the side of the defence. Although at this stage the accused could not have an attorney present (or do not even know that he is suspected of committing a crime), the judge cannot fill in the process for a missing party. Quite the contrary - he sees to it that the prosecutor and the police authority do not abuse such situation. Procedurally disadvantageous position of the defence can compensate by other means, as will be explained below.

\subsection{Applicability of the read testimony in the court}

If it the testimony was made under $\$ 158$ a of the Criminal Procedure Code as an urgent or unrepeatable act, it will be possible (as mentioned) to read the protocol about it in court instead of re-examination of the witness, which is enabled by $\$ 211$ par. 2, point. b) of the Criminal Procedure Code. The accused has, however a right to examine witnesses who are testifying against him. The impossibility to examine or to have the witnesses examined by his attorney, to ask them supplementary questions in the trial, as well as to allow the court to, on the basis of direct observation of responses and reactions of the witness, independently evaluate their authenticity, is seen as a breach of the right to defence, by extension, the right to a fair trial, because Article. 6 par.1, 3 point. b) ECHR defines among other things the right ot fair trial as the right "to examine or have examined witnesses against him and to obtain the attendance and examination of witnesses on his behalf under the same conditions as witnesses against him."

The Czech Constitutional Court and also the European Court of Human Rights (ECtHR) have already dealt with constitutionality of $\$ 211$ par. 2 point b). They both have consistently ruled in previous decisions, that the fact that during the trial was the questioning of the witness conducted via reading of the protocol from the questioning of the absent witness does not automatically imply a breach of Art. 6 par. 1 and 3, points. d) of the Convention, especially if the legal representative of the accused was properly and timely informed about questioning of a witness in the investigative stage and yet this did not attend the interrogation. Art. 6 ECHR in fact allows the courts to base convictions on previous testimony under two conditions: if the fact that the witness was not confronted with the accused is the result of a real impossibility to find a witness, it must be established that the competent authorities have actively searched for the witness to enable such a confrontation. The second condition is that the questionable testimony cannot in no case represent the only convicting evidence for the accused. ${ }^{18}$

\subsection{Admission read witness testimony in the judicature of the Czech Con-}

18 E.g. Gani against Spain, judgment of 19.2. 2013 application no. 61800/08; further example. Constitutional Court dated 17. 12. 2007, Ref. I. ÚS 375/06. 


\section{stitutional Court and ECtHR}

In accordance to the limitations mentioned above, the Constitutional Court assessed the case, which concerned human trafficking for sexual purposes. In II. US 573/08 the testimonies of victims who have been a Romanian citizen were taken as an urgent or unrepeatable act because they claimed that they wanted to leave the Czech Republic and return back to Romania before initiating the prosecution. The Constitutional Court found no procedural mistake of courts on the question of the admissibility of these evidence (the attempt of trial subpoena failed because witnesses were already abroad), but especially because it was not the only incriminating evidence and it was necessary to take into account the priority of the need to protect the rights and freedoms of injured person in the mode of active duty of the Czech Republic, as set out in the International Convention for the Suppression of the Traffic in Persons and the Exploitation of the Prostitution of another.

The necessity of the questioning of an absent witness not to serve as the only incriminating evidence of guilt, confirmed the ECtHR a few years later in exactly the same case, human trafficking for sexual purposes, of a Romanian citizens, who were questioned in the same way, and their testimony was used in the completely same manner as in the above case of the Constitutional Court. This was the case BREUKHOVEN against the Czech Republic and the ECtHR this time criticized the authorities responsible for criminal proceedings that they did not make reasonable efforts to ensure the presence of witnesses during the proceedings. ECtHR stressed that although the confrontation with the perpetrator could be bruising for victims of sexual offenses, states are obliged to take measures to offset the disadvantageous position of the defence. This rigorous assessment and finding of a violation of Article 6, par. 1 and 3 points. d) of the Convention stemmed mainly from the fact that the criminal offense in this case, the complainant established only using the testimony of witnesses mentioned that the defence was not able to hear. ${ }^{19}$

\section{British model of the "Hearsay rule"}

A variant of the admissibility of the read prior testimony are under the law of the United Kingdom called Hearsay, which have in the Anglo-American legal system a long tradition. Admissible in civil cases, however as to the applicability of the admissibility in the criminal proceedings, the general rule is for the hearsay testimonies to be inadmissible. The practice, on the other hand, eventually deducted the need to apply the "Hearsay rule" on criminal proceedings; the current doctrine speaks of "the exceptions to the Hearsay rule." ${ }^{20}$ These exemptions

19 BREUKHOVEN against the Czech Republic, Grand Chamber judgment of 21 7. 2011, Application no. 44438/06, ECtHR 2011, $\$ 46-58$.

20 see e.g. JEFFERSON, Bernard, S. Declarations against Interest: An Exception to the Hearsay Rule. Harvard Law Review, 1944, vol. 58, No. 1, p. 1-69; SELIGMAN, Eustace. An 
are regulated in the law, namely the Criminal Justice Act 2003 (CJA). Under $\$$ 114 of the CJA is as Hearsay considered any statement of the facts relevant to the criminal case that was made other than directly by the courts person that these facts directly perceived by his or her own senses. For the admissibility of such evidence in proceedings before a criminal court the British law sets conditions for its acceptability and usability. Therefore, in order for Hearsay to be used in criminal matters as well as it is according to $\$ 114$ of the CJA required that the admission is in the public interest, witness is objectively unable to attend the court proceedings, the evidence may be contained in a document that could not be issued to a court, or it is a testimony of someone else, indeed the "hearsay" testimony by the definition, the witness is unable to testify, etc. ${ }^{21}$ British common law also establishes three principles that need to be respected as a prerequisite for admissibility of the Hearsay:

1. The judges have discretion to decide on the exclusion of the Hearsay evidence in the case, if the effect of such testimony presented such serious prejudice of the rights of the accused, that the disadvantageous position in the process would not be balanced by the probative value of the testimony, ${ }^{22}$

2. In implementation of the Hearsay judge is obligated to inform the jury that it is the Hearsay evidence and to consider this fact when deciding the verdict,

3. If the jury concludes that the accused is guilty based on evidence obtained through Hearsay they must demonstrate by the other findings that the defendant's guilt can be proved beyond reasonable doubt.

\section{Shift of opinion in the case law of the ECtHR}

\subsection{Previous testimony and Hearsay rule}

Revolution in considering the admissibility of read witness statements was caused by the decision of the ECtHR in the cases of Al-Khawaja and Tahery against the United Kingdom. In the first of these proceedings, doctor Al-Khawaja was convicted on two counts of indecent assault, the allegations related to his treatment of patients under hypnotherapy. The hearsay issue arose because one of the complainants committed suicide prior to the trial. Her testimony, however, the judge considered crucial, named her as the legally permitted exception to the Hearsay rule and as such he read it to the jury, which subsequently agreed to the guilt of the accused.

Exception to the Hearsay Rule. Harvard Law Review, 1912, vol. 26, No. 2, p. 146-160 or RAKOS, Richard, F., LANDSMAN, Stephan. Researching the hearsay rule: Emerging findings, general issues, and future directions. Minn. L. Rev., 1991, No. 76, pp. 655-692.

21 FENNER, Michael, G. The Hearsay Rule. 3. edition. Carolina Academic Press, 2013, pp. 17-18.

$22 \$ 78$ of the Police and Criminal Evidence Act 1984 
Al-Khawaja after an unsuccessful attempt to overturn the guilty verdict at the Court of Appeals applied to the European Court of Human Rights, where he asserted the violation of Article 6 par. 1, 3 point. d) of the Convention. The Strasbourg Court joined the case Al-Khawaja with another case based on the so-called Hearsay. In the case Tahery the accused was convicted on the basis of the read testimony of a witness from pre-trial proceedings, who refused to repeat testimony in court, reportedly due to fear for his live and health, as well as the life and health of his family. ECtHR in both cases reiterated the principle of the inadmissibility of a read testimony of a witness as single exclusive or decisive evidence indicative of guilt of the accused and found violations of the European Convention in Article 6.

On the proposal of the Government of the United Kingdom, however, the two joined cases were referred to the Grand Chamber, because the same question of the admissibility of the Hearsay faced the Supreme Court of the United Kingdom once again, this time in the case of Horncastle and others against the United Kingdom ${ }^{23}$, which was a combination of both previous cases. The accused in the Horncastle case were sentenced on the basis of the testimony of witnesses, out of whom two died before the main trial, the other two did not arrive in court because of the fear for their own lives and health. The British Supreme Court faced a difficult question: follow the existing case law of the ECtHR, as is clear from the Act on the Protection of Human Rights ${ }^{24}$, or decide the case according to the traditions of common law, which generally admit Hearsay as evidence? If they choose to follow the path of ECtHR case law, it would generally mean that the Hearsay should not be allowed which could represent a substantial breach of the legal theory of evidence with a long tradition in England, and such a huge change could lead to a considerable reduction in the efficiency of English criminal justice system. ${ }^{25}$

The British Supreme Court has therefore decided to go the way of tradition and apart from a convicting the accused in the case Horncastle and others against the United Kingdom, the Supreme Court of UK initiated judicial dialogue, where the United Kingdom through Lord Phillips pointed precisely to the diversity of evidence according to British common law and the nature of the process resulting in inability to identify which evidence is sole or decisive against a defendant. ${ }^{26}$

$23 R v$ Horncastle and others from the 9th December 2012 [online]. Supremecourt.uk, 2009 [cit. $8^{\text {th }}$ December 2015]. Available at $<$ https://www.supremecourt.uk/decided-cases/docs/ UKSC_2009_0073_Judgment.pdf $>$.

$24 \$ 2$ par. 1 of he Human Rights Act 1998.

25 KOPA, Martin. Justiční dialog jak se sluší a patří [online]. Jinepravo.blogspot, 27th December 20142009 [cit. $8^{\text {th }}$ December 2015]. Available at <http://jinepravo.blogspot.fr/2014/12/ justicni-dialog-jak-se-slusi-patri.html>.

26 REDMAYNE, Mike. Hearsay and Human Rights: Al-Khawaja in the Grand Chamber. The modern Law Review, 2012, vol. 75, No. 5, p. 867 
The result of this dialogue between the ECtHR and courts of the United Kingdom concerning admissibility of the Hearsay evidence was a reinterpretation of existing case law of the ECtHR, which is reflected not only in the case of Horncastle and others against the United Kingdom, but also in the decision of the Grand Chamber in the referred case Al-Khawaja and Tahery against the United Kingdom. ${ }^{27}$

The ECtHR has formulated new criteria for the assessment of the opposition in the field of Art. 6, par.3 point. d) of the Convention in the absence of the witness at the trial. It was noted that these objections can be evaluated from three aspects. Above all, it is necessary to examine whether the fact that the defence does not have the opportunity to hear, or have prosecution witness examined, given a compelling reason. If not, it should be observed as violations of the Convention regardless of what is the weight of such evidence at issue. If there is no questioning of a witness and an important reason for such action lacks, the statement of the witness in principle cannot be regarded as exclusive or decisive evidence of guilt. However, if it is admitted as evidence testimony of a witness whom the defence had the opportunity to listen, and this testimony constitutes "sole or decisive" evidence against the defendant, its admission as evidence will not automatically result in a breach of Article 6, par. 3 point. d). At the same time where a conviction is based solely or decisively on the evidence of absent witness, the Court must subject the proceedings to the most searching scrutiny. Because of the dangers of the admission of such evidence, constitute a very important factor in the proceedings as a whole. Decision rendered in such proceedings can be legal only if some guarantees are met, including the existence of strong procedural safeguards. The question in each case is whether there are sufficient counterbalancing factors in place, including measures that permit a fair and proper assessment of the reliability of that evidence to take place. This would permit a conviction to be based on such evidence only if is sufficiently reliable given its importance in the case. ${ }^{28}$

The Grand Chamber of the ECtHR after the abovementioned three-step test finally admitted that in the case of Al-Khawaja there was no infringement of the right to a fair trial because the prosecution was fair as a whole, whereas in the case Tahery against UK Article 6 had been breached.

One could summarize the key for assessing the admissibility of the testimony of an absent witness would therefore now answer the question whether there was a compelling reason for the fact that the defendant had no opportunity to listen to and question the witness and to have them questioned, further what was the significance of such a testimony for the conviction of the accused, and finally,

27 See the Conclusion of judicial dialogue between ECtHR and UK courts on use of hearsay evidence, ECtHR 376 (2014) from 16th December 2014.

28 REDMAYNE, Mike. Hearsay and Human Rights: Al-Khawaja in the Grand Chamber. The modern Law Review, 2012, vol. 75, No. 5, p. 867. 
whether there have been given relevant procedural safeguards able to compensate for disadvantages arising for the accused from admitting such testimony. ${ }^{29}$

\subsection{Stealth / anonymous witness}

Testimonies of secret or anonymous witnesses create a specific type of witness testimonies. The accused is usually allowed to question or have the witness questioned or to be present at his interrogation, but only to the extent that does not endanger the disclosure of the identity of this witness. The ECtHR has repeatedly stated that it recognizes the need to implement these evidence because they are still one of the most effective methods to combat organized crime, but subsequent use of anonymous statements as evidence brings application problems of the need to balance the imbalance in the rights of to the defence with others procedural safeguards of a fair trial.

Such testimony could be used if the condition of subsidiarity (to anonymise witnesses only, when their protection could not be ensured otherwise) and proportionality (if there is indeed such a need to restrict the rights of the defence) is held. In such a case there is conflict between principle of fair and equitable process and reasonable effort to protect the public from the legislature upsurge in crime (especially organized crime) on the other hand. In case III. US 210/98, the Constitutional Court dealt with the admissibility of the questioning of two witnesses who bought drugs from the defendant (the complainant). Both witnesses were interrogated in secrecy, but always in the presence of defence counsel through a device in which their voice is transmitted into the next room, where he was present. In this case the defence counsel had the possibility of full intervention and, therefore, the Constitutional Court rejected the complaint as unfounded..$^{30}$ This attitude of the Constitutional Court has shown its goodwill to accept the testimony of the secret witness, however, only in case where the secrecy was justified.

When we talk about a secret witness, of course we have to mention the secret agent - policeman. This police-agent, due to his profession, must remain secret in court. One of these cases was the decision in the case of Lüdi against Spain, where the ECtHR found a violation of Art. 6 par. 1 and 3 points. d) of the Convention. According to the complainant, all charges in his case were based solely on the report of a secret agent and records of telephone conversations between the complainant and the agent who acted as interested in buying drugs from the complainant. At no stage of the prosecution had accused the possibility to question or have the agent questioned. The Agent has never been summoned as a witness (the reason being the reported effort to preserve the anonymity of police agents and it particularly their ability to infiltrate circles of drug traffick-

29 Constitutional Court judgment of 3 March 1999. No. III. US 210/98.

30 Judgment of the European Court of Human Rights Lüdi against Spain, judgment of 15. 6. 1992. 
ers), which prevented the court to make their own opinion about the credibility of such witness. While the witness was a person in active service, whose function was known to the investigating judge, the accused also met the witness on several occasions (meetings for the purpose of drug trafficking), ie at least the physical appearance of the agent (though not his true identity) has already been known. Based on these facts, the ECtHR found the secret witness in proceedings before the court (as well as the inability to question him) as infringing Art. 6 par. 1 and 3 points. d) of the Convention.

Worth mentioning is certainly another decisions of the ECtHR, this time in the case Pesukic against Switzerland. In this case ECtHR comments on certain technical aspects of taking evidence from anonymous witnesses. In connection with this case, the question arose, whether the ECtHR has not deviated from its earlier case law and did not incline to moderate demands for questioning an anonymous witness, while admitting a higher (in this case, perhaps even to the extreme) restriction of the right to defence. Briefly it was the following facts: the complainant (Pesukic) was convicted for the crime of murder based on the testimony of an anonymous witness, who was questioned separately from the accused, and whose voice was modulated. The witness stated that the accused and the people close to pose a reasonable threat to his life, which the court found to be relevant and provide him with all possible procedural safeguards preventing his identification, including the possibility to leave some questions unanswered. The ECtHR therefore discussed the importance of such testimony, because according to its own previous cases, testimony of an anonymous witness cannot serve as the sole incriminating evidence. From the analysis of the judgment it is evident (among other also from the fact that the ECtHR proceeded to the next step of the so-called. Test Al-Khawaja), that even when the court does recognize the impact of their own decisions, this testimony was ultimately found to be evidence "having a significant impact", thus the evidence is in this case essentially a key proof. V. Nejedly recognizes in this situation a baleful influence of the Grand Chamber judgment in the case of Al-Khawaja and Tahery against the United Kingdom having impact also on the questioning of secret witnesses, because in his opinion, the ECtHR would certainly have found a violation of the right to a fair trial, if not for the above mentioned decisions. ${ }^{31}$

After the ECtHR admitted this evidence, the court had to cope with the next step of the Al-Khawaja test, comparing the appropriateness of limiting the rights of the defence and balancing of procedural measures to address this discrepancy. Undoubtedly the fact that neither the applicant/accused nor his representative had the opportunity to question the witness and to observe and watch his immediate responses to the questions, notwithstanding the fact that most of the questions that the witness was asked, were not answered at all, represents a very sig-

31 NEJEDLÝ, Josef. Věc Pesukic proti Švýcarsku, anonymní svědek a právo vyslýchat svědky proti sobě. ASPI, cit. 18. 11. 2014. 
nificant interference with the right to defence. If we compare this case with, for example the Van Mechelen case, where it was found that an extreme violation of the rights of the accused to discuss the damning evidence is the situation where the witnesses (policemen) are during interrogation in the same room as the investigating judge, accused and their legal representatives, however, were dismissed from this room and communication could take place only using sound equipment, ${ }^{32}$ we have to admit that in the case was Pesukic was the interference with the rights to defence more significant.

It can be summarized that the ECtHR did not stretch with the need to compensate for the limitation of the rights to the defence with more favourable procedural conditions. Although the judgment is quite justified in detail, in this regard, the Court reconciled with the fact that a witness during the questioning could have been observed by all members of the jury and they were able to make up their own mind about his credibility, and that the witness was questioned directly by the presiding judge instead of a prosecutor. Apparently these facts were sufficient for ECtHR as a procedural safeguards and balance to the rights to defence.

Probably in an effort to establish the conditions under which it can be stated that the questioning of an anonymous witness still meets the requirements of a fair trial, established in the case Kok against the Netherlands, ${ }^{33}$ ECtHR formulated following criteria: the reasons for securing the identity of the witness, the weight of the evidence for a conviction and compensation for the limitations of the defence. The criteria are mostly similar to the admissibility criteria formulated in previous decision, namely Al-Khawaja and Tahery against the United Kingdom. Thus, we can conclude that the conditions for admission of the read testimony of a person who testified only in pre-trial proceedings are comparable to the admissibility of anonymous testimony as evidence. Based on these identified similarities I would add one more condition: assuming that anonymous testimony will pass the above-mentioned three-step test for the applicability is essential that the testimony does not stand by itself as the sole and exclusive proof of guilt of the accused, unless at the same time an adequate procedural compensation for disadvantages on the side of the defence is provided.

Other specific category is composed of testimonies taken before prosecution, for example the testimonies of victims of sexual offenses, especially when it comes to juvenile victims of or children. This issue is very sensitive, because here come into consideration the risks known as so called secondary victimization, a form of secondary psychological damage to the victims. ${ }^{34}$

32 Judgment of the European Court of Human Rights Van Mechelen and others against the Netherlands dated 23. 4. 1997

33 Kok against the Netherlands, a decision on the unacceptability of 4. 7.2000 Application no. 43149/98, ECtHR 2000-VI.

34 for more info see ŠČERBA, Filip. Obět’ sexuálně motivovaného deliktu jako důkazní 


\section{Impact of decisions of the ECtHR on the case law on the Constitutional Court}

In one of the first cases following the case of Al-Khawaja and Tahery against the United Kingdom the Constitutional Court complied with constitutional complaint in a retrial after the judgment of the European Court of Human Rights in the case Igor Tseber against Czech Republic (Pl. US 25/13). The Constitution Court partially annulled the criminal judgments of ordinary courts, according which the complainant was found guilty of a series of violent crimes, including battery, which he was supposed to cause to a person V.O. (injured party). The testimony of the injured party, whom the complainant allegedly had shot through the leg and who reportedly out of fear of vengeance did not attend the trial, was then read out in court, referring to the fact that the very testimony of a witness / injured party was conducted as an urgent act. Witness was at the time of questioning in serious condition treated in intensive care. The complainant objected, of course, that he had never had the opportunity to question the witnesses and that such evidence cannot be (with regard to the case law of the ECHR) sole or decisive evidence of guilt and is a violation of Article 6, par. 1 and 3 points. d) of the Convention.

In previous proceedings before the European Court for Human Rights, also in this case, where the complaints examined under the criteria of the Al-Khawaja test. From the perspective of the first criterion, namely whether in the present case there is a compelling reason for the fact that the witness could not be subjected to the questioning from the defence, the court concluded that for reading of the testimony of a witness was in this case given a compelling reason, because the court made attempts to find a witness and to summon him to the trial. Only when all the attempts failed, the presiding judge decided to take evidence by reading the testimony.

In assessing the second criterion ECtHR examined how far the disputed testimony influenced the decision to convict the complainant, therefore, whether the statement represented the exclusive or decisive evidence of guilt of the defendant. Although the European Court has confirmed that the courts took into account other evidence than just this controversial testimony, but the truthfulness of the claim that the injury was caused by a criminal offense of the complainant could be proved only by this testimony. Thus, the absent witness testimony represented a decisive proof of guilt because of other evidence only indirectly promoted or reinforced court's confidence in the victim's claims.

The third aspect, therefore, the need to consult on the fairness of the process as a whole, particularly with regard to the need to balance the disadvantageous position of the defence in cases where the testimony is read or in situations of

prostředek. In Dny práva 2014. Sborník př́ispěvků z konference Dny práva 2014, Brno: Masarykova Univerzita, 2014. 
an absent witness, the ECtHR ruled that neither the presence of a judge at the questioning of a witness can be considered measures that would be able to compensate the absence of the accused in witness interrogation. Based on the above, the ECtHR ruled that the in the case of complainant Tseber there was a violation of the right to a fair trial under Art 6, par. 1 and 3 points. d) of the Convention ${ }^{35}$, which is reflected in the subsequent decision of the Constitutional Court, which, as stated above, upheld the constitutional complaint and annulled the previous rulings of the general courts.

\section{Conclusion}

Evidence in the form of reading the testimony of a witness, who had never been questioned by the defence in an adversarial hearing, constitutes undoubtedly noticeable interference with the rights of the defendant and such as is contrary to the requirements of adversarial proceedings. Given the need to determine as accurately as possible the actual facts of the case in the absence of other admissible evidence, even reading the record of the previous testimony of a witness who is absent due to objective reasons can be admitted and it $t$ necessarily does not constitute a violation of the right to a fair trial. The evolving judicature of the European Court of Human Rights even admits that the testimony of an absent witness could be used as sole or decisive evidence of guilt, and to assess whether the procedure does not cross beyond the right to a fair trial, was formulated three-step test. However, one cannot overlook that, although the evidence before the ordinary courts takes place entirely in accordance with the laws of the Czech Republic (namely the Criminal Procedure Code) application of $\$ 211$ par. 2 of the Criminal Procedure Code often creates violation of the right to a fair trial, specifically Art. 6, par. 1 and 3 points. d) of the Convention, even in strict compliance with all the mentioned steps called Al-Khawaja test. The question therefore arises whether the formulation of exceptions to the principle of adversarial and oral proceedings, as contained in $\$ 211$ par. 2 point, b) of the Criminal Procedure Code and the institute urgent or unrepeatable acts in accordance with $\$ 158$ a of the Criminal Procedure Code are not themselves contrary to the European Convention on Human Rights? According to The ECtHR they are not, however, de lege ferenda, it would be probably appropriate to prevent any doubts about the admissibility of such evidence that by incorporating some sort of correction principle into the Criminal Procedure Code that would reflect the challenged provisions of the Convention. In its essence, this provision would preclude the general courts to convict an accused to a decisive extent on the testimony of a witness or witnesses who had not have the accused or his lawyer the opportunity to hear and question. The same would apply in the case of witnesses that the defence had an opportunity to question, but the interrogation was considerably hampered by keeping witnesses true identity secret. Another solution,

35 Joined Cases 11/22 2012 Application no. 46203/08.

(c) Palacký University Olomouc, Czech Republic, 2015. ISSN 1213-8770 (print), ISSN: 2464-6601 (online). 
ICLR, 2015, Vol. 15, No. 2.

or rather the inspiration for the preservation of one own legislation may be seen in United Kingdom where was successfully preserved an institute that caused in terms of ECtHR constant judicature problems. England, however, defended his Hearsay, as to how will the Czech lawmaker react on is constant criticism from the ECtHR in connection with the planned re-codification of the Criminal Procedure, it is not clear yet. 